\title{
PAX6 gene analysis in Serbian patients with aniridia
}

\section{Ispitivanje sekvence PAX6 gena kod pacijenata sa aniridijom}

\section{Dimitrije Cvetković ${ }^{1}$, Jelena Cuk ${ }^{1}$, Ivana Novaković1,2}

\author{
${ }^{1}$ Medicinski fakultet Univerziteta u Beogradu \\ ${ }^{2}$ Mentor: Institut za humanu genetiku, Univerzitet u Beogradu
}

Kontakt: cvetkovic.d@outlook.com

Sažetak

Uvod: Aniridija je retka kongenitalna anomalija oka, praćena različitim oftalmološkim tegobama. Uzroci ovog oboljenja su mutacije u PAX6 genu (engl. paired box 6, gen sa blokom koji kodira parni domen) ili delecija lokusa na kratkom kraku jedanaestog hromozoma koja može da bude parcijalna ili kompletna. U ovoj studiji je ispitivana sekvenca PAX6 gena kod četiri nesrodna bolesnika sa aniridijom.

Cilj: Ispitavanje celokupne kodirajuće sekvence PAX6 gena kod naših bolesnika u cilju otkrivanja mutacija u ovom genu.

Materijal i metode: Iz uzoraka periferne krvi izolovana je DNK bolesnika. Nakon toga je metodom polimerazne lančane reakcije (PCR metodom) izvršena amplifikacija kodirajućih PAX6 egzona i graničnih regiona i dati uzorci su direktno sekvencirani metodom po Sangeru.

Rezultat: Kod jednog bolesnika je nađena mutacija po tipu insercije (c.342-2insC) u drugom intronu PAX6 gena. Kod preostala tri bolesnika nije nađeno odstupanje u sekvenci PAX6 gena.

Zaključak: Ovo su prvi rezultati analize PAX6 gena u Srbiji. Osim najčešćih mutacija, delecija različitog obima u kodirajućem regionu ovog gena, mogući uzroci aniridije su i druge vrste mutacija. Insercija pronađena u ovoj studiji nije prijavljena ranije. Moguće je i da su mutacije u drugim genima povezane sa malformacijama dužice, što može da objasni nalaz normalne sekvence kod tri bolesnika sa aniridijom.

Ključne reči: aniridija, PAX6 gen, kongenitalne anomalije oka

\section{Introduction}

PAX6 gene belongs to the family of Pax genes and it plays an important role in the formation of tissues and organs, in the course of embryonic development. Members of this gene family are also involved in maintaining the function of cells after birth. Pax genes maintain its role through various proteins (transcription factors) that bind to target places of the regulatory DNA, thus control the expression of many other genes (1).
Abstract

Introduction: Aniridia is a rare congenital eye anomaly associated with various ophthalmological problems. Some of the causes of this disease are mutations in the PAX6 gene or deletion of loci on the short arm of chromosome eleven, which can be complete or partial. In this study, PAX6 gene sequence was analysed in four unrelated patients.

Aim: Examination of the entire coding sequence of the PAX6 gene in our patients in order to detect mutations in this gene.

Material and Methods: Patients' DNA was isolated from samples of peripheral blood. All exons and flanking intronic sequences of the PAX6 gene were amplified using PCR and screened for mutation with direct DNA sequencing by Sanger method.

Results: In one patient, the insertion type of mutation (c.342-2insC) was found in the second intron of the PAX6 gene. Other three patients had normal PAX6 sequence although they had phonotypical expression of aniridia.

Conclusion: These are first results of PAX6 gene analysis in Serbia. Apart from most common mutations, deletions of various extent in coding regions of PAX6 gene, other types of mutations are also possible causes of aniridia. The insertion found in this study has not been reported before. It is also possible that mutations in other genes are associated with iris malformation, which can explain the finding of normal PAX6 gene sequence in three patients with aniridia.

Key words: aniridia, PAX6 gene, congenital eye anomaly, Serbia

In the human genome, PAX6 gene is located on the short arm of chromosome 11 at position $11 \mathrm{p} 13$ and consists of 14 exons (2). During embryonic development PAX6 proteins activate genes involved in the formation of the eye, olfactory regions of the brain and spinal cord. Mutations in the gene PAX6 are primarily associated with malformations of the eye and from these disorders, the most notable is aniridia (1).

Aniridia is a structural eye disorder, which is characterized by complete or partial absence of the iris of the 
eye. Glaucoma, cataract, strabismus and foveolar hypoplasia are often associated with this disorder (3). Also, the deletion of a large scale in $11 \mathrm{p} 13$ region can lead to WAGR syndrome, which is characterized by Wilms' tumor, aniridia, genitourinary malformations and mental retardation (4).

The aim of this study was to examine whether there is a change in the sequence of PAX6 gene in four patients with aniridia.

\section{Material and methods}

The study included four unrelated patients diagnosed with aniridia. Molecular genetic analysis was conducted in genetic laboratories of the Department of Neurology, Clinical Center of Serbia, Belgrade.

Entire coding region of the PAX6 gene (exons 3-14), including exon - intron boundaries, has been analyzed. After the DNA extraction, we performed Polymerase chain reaction (PCR), in order to amplify target PAX6 regions. Depending on used primers, products of PCR amplification showed different size.

PCR reaction mix was consisted of:

Dream Taq 10x PCR buffer: $2,5 \mu$,

10mM dNTPs: $0,5 \mu \mathrm{l}$,

primer fw and $\mathrm{rv}$ (10 pmol): $0,5 \mu \mathrm{l}$ each,

Dream Taq polymerase $(5 \mathrm{U} / \mu \mathrm{l}): 0,2 \mu \mathrm{l}$,

DNA (10ng/ $\mu \mathrm{l}): 2 \mu \mathrm{l}$,

$\mathrm{H} 2 \mathrm{O}$ to $25 \mu \mathrm{l}$.
PCR conditions followed touch down protocol:

1. initial denaturation $950{ }^{\circ} \mathrm{C} 10$ min.; 10 cycles (steps 2-4):

2. denaturation $950^{\circ} \mathrm{C} 1$ minute

3. primers' annealing $650^{\circ} \mathrm{C} 1$ minute

4. elongation $720^{\circ} \mathrm{C} 1$ minute; 20 cycles (steps 5-7)

5. denaturation $950^{\circ} \mathrm{C} 1$ minute

6. primers' annealing $650^{\circ} \mathrm{C}$ to $550^{\circ} \mathrm{C}$ (decreasing temperature $0,50 \mathrm{C}$ per cycle) 1 minutes

7. elongation $720^{\circ} \mathrm{C} 1$ minute; 10 cycles (steps $8-10$ )

8. denaturation $95^{\circ} \mathrm{C} \mathrm{C} 1$ minutes

9. primers' annealing $550^{\circ} \mathrm{C} 1$ minute

10. elongation $720^{\circ} \mathrm{C} 1$ minutes

11. final elongation $720^{\circ} \mathrm{C} 8$ minutes

After purification of PCR products by ExoSap method, we performed direct sequencing of PAX6 fragments by Sanger method, using BigDye Terminator chemistry. Capillary electrophoresis for DNA sequencing was done on ABI 3500 Genetic Analyzer (Life Science, USA), together with data analyzed by Sequencher software.

\section{Results}

In one patient, the insertion of one base pair was found in the second intron (c.342-2insC) of PAX6 gene. This change in sequence has led to different processing of primary mRNA transcript. By Sequencher software prediction, it is, most probably, responsible for the phenotypical change.

Other patiens had no mutation in the PAX6 gene, although they had phenotypic expression of aniridia.

Table 1. Primers' sequences used for PAX6 gene analysis

\begin{tabular}{ll}
\hline Primer & Sequence \\
\hline Primer 3f & CCA-TGG-ACG-TAT-GCT-GTT-GA \\
Primer 4f & ACC-TCG-GTT-GGG-AGT-TCA-G \\
Primer 5f & CTC-TTC-TTC-CTC-TTC-ACT-CTG-C \\
Primer 6 + 7f & CAG-TAA-GTT-CTC-ATA-CCA-TTG-AAG-G \\
Primer 8f & TGG-GTG-ACT-GTG-TCT-TCA-GG \\
Primer 9f & AGA-CTA-CAC-CAG-GCC-CCT-TT \\
Primer 10f & AGG-TGG-GAA-CCA-GTT-TGA-TG \\
Primer 11 + 12f & GGG-CTC-GAC-GTA-GAC-ACA-G \\
Primer 13f & GTG-GCT-GTG-TGA-TGT-GTTCC \\
Primer 14f & TTC-CAT-GTC-TGT-TTC-TCA-AAG \\
\hline
\end{tabular}


a)

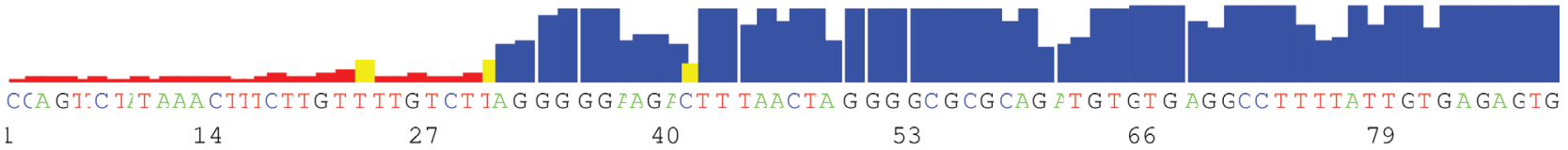

40

53

66

79
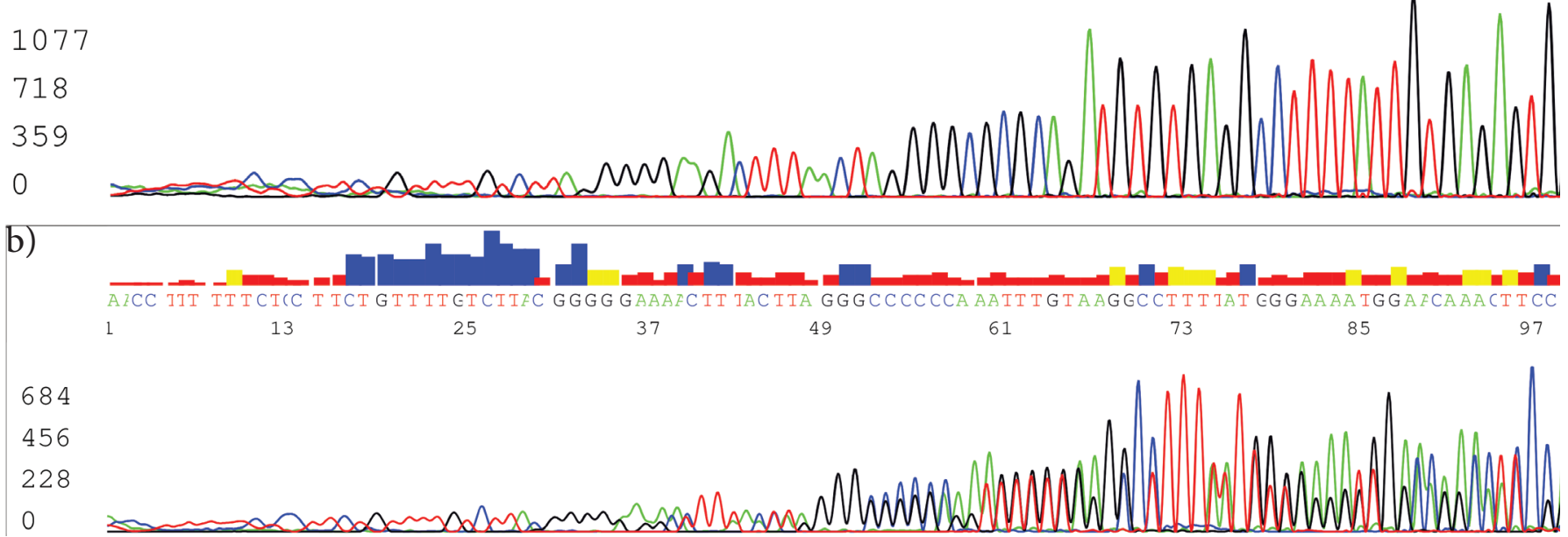

Figure 1. Electropherogram of the border region of intron 2 and exon 3 in PAX6 gene: a) a reference sequence, b) insertion of $1 \mathrm{BP}$ within the consensus sequence $\mathrm{AG}$ at the turn of introns and exons

\section{Discussion}

PAX6 gene sequences analysis has not been done in our country and these studies are generally rarely performed in Europe. Although there are no recent data on the frequency of aniridia in Serbia, the prevalence of this disorder in the general population is $1: 50000-100000$ (5), while in Northern European countries $1: 72000$ (6).

In our study, insertion type of mutation (c.342-2in$\mathrm{sC}$ ) is determined in non-coding (intron ) part of the PAX6 gene sequences. According to PAX6 mutation database, this change has not been described previously. In the Korean study, three intronic mutations were observed, but at different locations. (7).

On the other hand, studies performed in China (8) and Poland (9), highlight deletions of different scope in coding regions of the PAX6 gene as the main cause of aniridia.

In the Polish study, the normal sequence of the PAX6 gene was found in three patients, as well as in three of our patients(9). The conclusion is that the iris malformations in these patients may be due to mutation in another gene that has a role in the formation of the eye, and thus aniridia is phenotypically present (9). This has been supported by results of the study which showed that mutations in the CYP1B1 gene can lead to the appearance of congenital aniridia and glaucoma (10).

These are first results of PAX6 gene analysis in Serbia. Apart from the most common mutations, deletions of various extent in coding regions of PAX6 gene, other types of mutations are possible causes of aniridia, but the evidence for this is scarce. This is just one piece of the puzzle and it is clear that further research is necessary, in order to be able to uncover the origin of this rare disease.

\section{References:}

1. Kokotas H, Petersen, M. Clinical and molecular aspects of aniridia. Clinical Genetics 2010;77: 409-420.

2. Zumkeller W, Orth U, Gal A. Three novel PAX6 mutations in patients with aniridia. MolPathol. 2003;56:180-183.

3. Gramer E, Reiter C, Gramer G. Glaucoma and frequency of ocular and general diseases in 30 patients with aniridia: a clinical study. Eur J Ophthalmol. 2012;22(1): 104 - 110.

4. Fischbach BV, Trout KL, Lewis J, Luis CA, Sika M. WAGR syndrome: a clinical review of 54 cases. Pediatrics (2005);116(4):984-988.

5. Crolla JA, van Heyningen V. Frequent chromosome aberrations revealed by molecular cytogenetic studies in patients with aniridia. Am J Hum Genet. 2002;71:1138-49.

6. Edén U, Iggman D, Riise R, Tornqvist K. Epidemiology of aniridia in Sweden and Norway. Acta Ophthalmol. 2008;86:727-9.

7. Park SH, Kim MS, Chae H, Kim Y, Kim M. Molecular analysis of the PAX6 gene for congenital aniridia in the Korean population: identification of four novel mutations. Mol Vis. 2012;18:488-94.

8. Chen P, Zang X, Sun D, Wang Y, Wang Y, Zhao X, et al. Mutation analysis of paired box 6 gene in inherited aniridia in northern China. 2013;1169-77.

9. Wawrocka A, Sikora A, Kuszel L, Krawczynski MR. 11p13 deletions can be more frequent than the PAX6 gene point mutations in Polish patients with aniridia. J Appl Genet. 2013;54:34551.

10. Alzuhairy S, Abu-Amero KK, Al-Shahwan S, Edward DP. A Novel CYP1B1 Mutation with Congenital Glaucoma and Total Aniridia. Ophthalmic Genet. 2015;36:1 89-91. 